\title{
Jewish Pilgrim at the Black Madonna
}

It was 6 June 1944-or perhaps I heard the news a day or two later, as notable events about the war often reached us some time later. I was always eager for Pani to come home with any news of the outside, but this time she brought the most dramatic news ever, coming straight from central Warsaw. Generally a placid person, Pani was in a high state of elation as she recounted the thrilling news that British and American forces had crossed the Kanal la Manche-for the English Channel is referred to in Poland by its French name-and landed on the French coast. Normandy was not mentioned by name at this time, only Kanal la Manche. I quickly fetched the atlas, and from it we naturally deduced that the Allies must have taken the shortest route and landed on the French coast somewhere near Calais. But the actual progress of the invasion force was not known to us, as we had no access to BBC broadcasts from London and were unable to follow the course of the fighting.

We'd had no idea the Allies were about to invade; we had only looked east, to Russia. Occasionally, Pani would bring home a secret bulletin, circulated by the Underground, but aside from those we had to rely on rumours, and one could never be sure where they originated from; only those from secret sources were considered reliable. Mostly they came from German "street barkers," or loudspeaker radios which spouted Nazi propaganda on the streets of Warsaw, giving out news that one had to take with a pinch of salt.

A Nazi party newspaper translated into Polish and circulated in the capital-I'm no longer sure, but it may have been called Nowy Kurier Warszawski-admitted that the landings had taken place. But the paper insisted that the Atlantic Wall was holding fast and that Festung Europa was impregnable, confidently predicting that the Allied invasion force would be thrown back into the sea. Pani brought home a copy of the issue, which she would not have done normally; good Poles didn't like to be seen buying German newspapers. However, this time she was tempted to get a copy out of sheer curiosity, in view of the dramatic news, and 
we were hungry for information. I listened intently as Pani tried to read between the lines, attempting to detect the propaganda lies put out by the Nazis. With the invasion of Europe finally on, and the Germans in full retreat, Pani got more talkative and described the various armies involved on the Allied side. She told us of the great resources and might of America, spoke in glowing terms of the Royal Navy, who "ruled the waves," and described the fighting spirit of the British "Tommy," whom she held in high esteem-well, almost as high as the soldiers of the Red Army!

This momentous news filled us with great hope. Surely the war could not go on much longer now, with the opening of the "Second Front" in Europe and the Allies firmly established on the mainland. What was more, a few weeks later, on 20 July, Pani reached home with yet another piece of sensational news: an attempt had been made on Hitler's life, and he might even be dead, despite of the strenuous denials of the "street barker."

As a result of all the dramatic news from the war fronts, I felt confident enough to slip out of the house in the evening once or twice, before the start of the curfew, to enjoy the welcome fresh air and to fill my lungs and stretch my legs, after having been confined indoors for six months. At first, my legs felt as stiff and foreign as yet-unused wings must feel to a fledgling. I kept trying to sprint away to see if I still remembered how to run and if I was as quick on my feet as I had once been.

In view of the continuous good news, Pani suggested that as a form of thanksgiving we would all go on an outing. And what better place to go than to the monastery shrine of the Holy Mother of Częstochowa? We would go there on pilgrimage to pray for early deliverance from the Nazis, and at the same time offer prayers for a cure for Wanda. This shrine is the foremost place of pilgrimage in Poland, dating back to the fourteenth century. It houses the Icon of the Black Madonna and Child. Pani suggested that it would be safe enough for me to come along as well, to which idea I readily agreed. I looked forward to coming out into the open after being shut away for so long. To mark the event, Pani wanted to make me look presentable to fit the occasion, so she gave me one of her "pudding-basin" haircuts, which was desperately needed, before we set out together-me, Pani, and Wanda in her wheelchair-on the thrilling journey. 
We travelled by train to Częstochowa, a town some distance to the west of Warsaw, on a glorious summer's day below a beautiful azureblue sky. It had rained during the previous night, and the air was clear, fresh and fragrant, heavily scented with the odor of Mock Orange, which people in Poland refer to as Jasmine. Anin was so beautiful and verdant; I had never seen it properly before. When I first got to Anin it was winter. How lovely the world looked that morning! I relished the liberty of moving about freely, listening to the birds chirping away noisily. It was wonderful to bask in the warm spring sunshine that I had been starved of for so long. It gave me an elated feeling in my head, as if I was floating on air. After being cooped up for so long, I wanted to remain outdoors in the fresh air and sunshine, just walking on and on, hoping the day would never end. Pushing Wanda' wheelchair, I skipped along as happy as a lark-now and then Wanda had to tell me to slow down!

By the time we reached the vicinity of Jasna Góra, a host of pilgrims was already there. They had been arriving since early morning, counting their Rosary beads along the way. In their exultation, the faithful kept repeating, "Our Father" and, "Glory Be" while eagerly pressing up the incline along the tree-lined avenue that led to the shrine. In their devotion, some penitents even walked on their knees for the last stretch, continuously intoning "Ave Maria," the prayer to the Virgin Mary, as they went. A pilgrimage to Our Lady of Częstochowa, who had the reputation of bestowing miracle cures, was of great spiritual significance at this turbulent time. The Madonna had been revered as the Queen and the Protector of Poland from foreign invaders throughout the country's troubled history. When we finally got near the image above the altar, I was rather surprised to find that the image was not very large, and that the sorrowful-looking Madonna was not really black but rather coffee-coloured, having darkened with age.

Religious passions were running high; the crowd was seething with patriotic zeal. Religion in Poland goes hand-in-hand with nationalism. This was not a very comfortable setting for a lone Jewish boy pretending to be something he was not-I felt like an unwelcome and not entirely sincere intruder, making the sign of the cross and going through all the motions. As the procession emerged from the church, holding aloft gold crucifixes, I was kneeling on one leg with the throng and felt the pungent whiff of the waving censer. Inside the Church during Mass, the Priest intoned the "Kyrie Eleison, Christe Eleison" as the worshippers responded, "In the name of the Father, the Son and the Holy Ghost, 
Amen." Something within me stopped me from going forward to the altar with Pani and Wanda to receive the Host in the form of a wafer, representing the body and blood of Christ. Although she never mentioned it, I somehow felt that Pani may have wanted me to go forward with her, but she could sense I was hesitating. In any case, it is a sin to take communion if one is not baptised, and she must have been aware of this. It was an ironic situation for a Jewish boy to find himself in, and I also got carried away in the religious fervour and prayed, not to an icon or effigy, but to the same Father in Heaven, in the only way I knew-the way I was taught as a boy at Hebrew school. I prayed for the protection of my family wherever they might be. I could never imagine that they were not well, or that any harm would ever come to them.

It wasn't comfortable to be a Jewish boy during these inquisitorial times. It would have been so much better to just give up being Jewish, but it isn't something one can do easily. Though I could try to deny my faith, I could never escape my destiny, because those around me would never let me. They would always keep reminding me, "A Jew will always be a Jew." Thus, I felt, I might as well remain what I was born into. I was compelled to deny my identity to stay alive, and at times I even regretted being Jewish, but deep down I could never forget who I was, and where I came from, whether it was here at Jasna Góra or when it later became prudent for me to be seen going to church on holy days.

Before we started back home, Pani offered to give us each a little souvenir to mark the occasion. Wanda chose some amulet or another to adorn her room, and I picked a picture postcard of the Black Madonna and Child as a keepsake.

Within days of our trip, as if all our prayers had been answered, the booming of heavy guns became clearly audible in Anin. This had to be the beginning of what I had waited and prayed so long for! We knew that the Allies had landed on the mainland of Europe, but we had no idea that the Russians were advancing rapidly through Poland. At night, one could see gun flashes in the eastern sky and a red glow on the horizon-a sure indication that the front line was drawing close to Warsaw, heralding our imminent liberation. I was too excited to go to bed that night, and stood on a chair by the window for a long time, with the lights out, gazing into the night sky and the gun-flashes in the distance. This had to be long-range Russian artillery, I thought. I was too excited to go to sleep. This must be it - the Red Army was on its way! The next day Pani 
and I went out on the streets and watched with glee as the Germans were feverishly preparing to pull out. They were loading up their trucks with fine furniture and desks-taking all their ill-gotten gains, no doubt confiscated from private homes, back with them to the Vaterland. I was so thrilled, I felt like leaping in the air for joy. The nightmare was at last coming to an end. I could hardly wait to see what the next day would bring. 